\title{
Primary septic arthritis of talonavicular joint
}

\author{
Hosam E Matar, Karthikeyan P lyengar, Eugene M Toh
}

Department of Trauma and Orthopaedics, Southport and Ormskirk University Hospital NHS Trust, Southport, Merseyside, UK

\section{Correspondence to}

Hosam E Matar,

hematar@doctors.org.uk

Accepted 25 February 2014

\section{DESCRIPTION}

Septic arthritis is an inflammation of a synovial membrane with purulent effusion into the joint capsule due to bacterial infection. The estimated incidence ranges from 2 to 10 cases/100 000 persons/ year in the general population with approximately $3-7 \%$ of septic arthritis involving the foot and ankle joints with the tibiotalar and the first metatarsophalangeal joints most commonly affected. ${ }^{1}{ }^{2}$ Septic arthritis often arises from a local inoculation or haematogeneous spread presenting acutely with hot swollen joint and inability to weight bear with severe pain on movements. Plain radiographs are typically non-specific but may demonstrate joint effusion. Once suspected, arthrocentesis should be performed, fluid analysis sent for microbiological cultures to identify the causative organism and appropriate antibiotics should be started promptly.

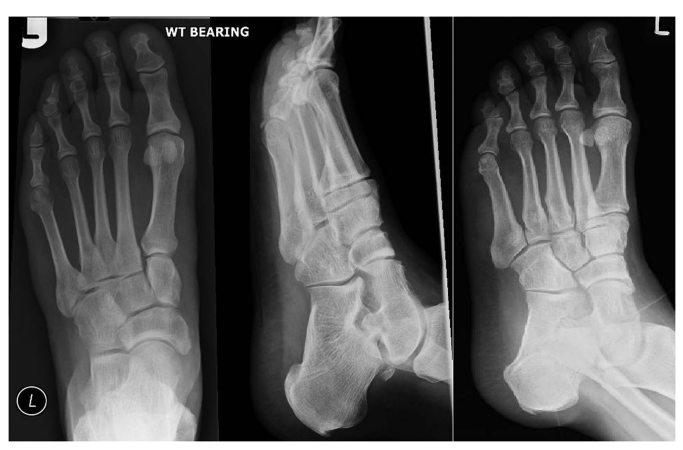

Figure 1 Anteroposterior, lateral and oblique plain radiographs of the left foot with no gross abnormalities.
We present a rare case of primary septic arthritis in the mid-foot (talonavicular joint) in a normally fit and well 43-year-old engineer who presented to minor injury units with 4 days history of painful left mid-foot, struggling to weight bear, and mildly raised inflammatory markers. Plain radiographs (figure 1) were essentially unremarkable. Few days later, he re-presented with increasing pain, redness, swelling of the mid-foot and raised inflammatory markers. MRI (figure 2) showed talonavicular joint effusion with surrounding soft tissue oedema, these are characteristic findings in septic joints. ${ }^{3} \mathrm{He}$ underwent surgical drainage, debridement and washout of the infected joint. Intraoperative histological and microbiological specimens identified Staphylococcus aureus as the causative organism. Appropriate antibiotics were administered.

\section{Learning points}

- Primary septic arthritis of the foot is extremely rare in otherwise healthy populations, however a monarticular arthropathy in the foot/ankle must be considered suspicious for infection.

- Plain radiographs may show soft tissue swellings but are frequently non-specific. However, joint effusion, perisynovial oedema, and synovial enhancement on MRIs are highly correlated with septic arthritis.

- X-ray-guided arthrocentesis or surgical exploration is often required for definitive diagnosis.

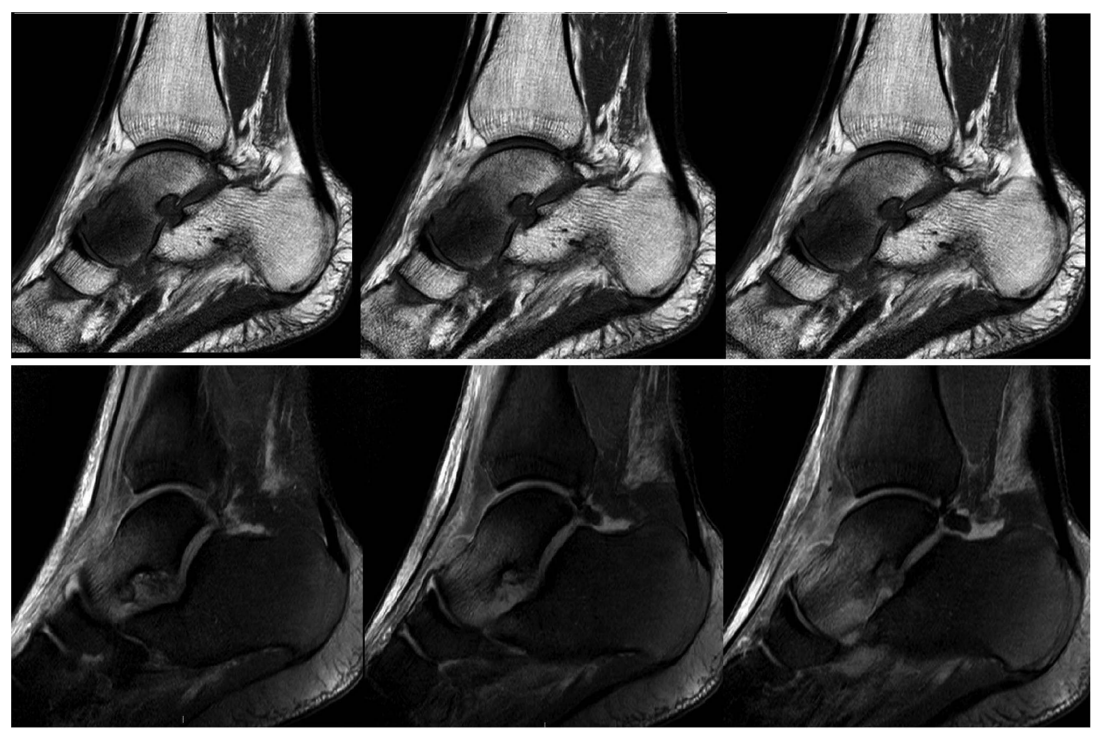

Figure 2 Sagittal MRI demonstrating bone marrow oedema in the body of the talus with localised talonavicular joint effusion and overlying soft tissue oedema. 
Competing interests None.

Patient consent Obtained.

Provenance and peer review Not commissioned; externally peer reviewed.

\section{REFERENCES}

1 Kaandorp CJ, van Schaardenburg D, Krijnen P, et al. Risk factors for septic arthritis in patients with joint disease. A prospective study. Arthritis Rheum 1995;38:1819-25.

2 Holtom PD, Borges L, Zalavras CG. Hematogenous septic ankle arthritis. Clin Orthop Relat Res 2008:466:1388-91.

3 Karchevsky M, Schweitzer ME, Morrison WB, et al. MRI findings of septic arthritis and associated osteomyelitis in adults. Am J Roentgenol 2004;182:119-22.

Copyright 2014 BMJ Publishing Group. All rights reserved. For permission to reuse any of this content visit http://group.bmj.com/group/rights-licensing/permissions.

BMJ Case Report Fellows may re-use this article for personal use and teaching without any further permission.

Become a Fellow of BMJ Case Reports today and you can:

- Submit as many cases as you like

- Enjoy fast sympathetic peer review and rapid publication of accepted articles

- Access all the published articles

- Re-use any of the published material for personal use and teaching without further permission

For information on Institutional Fellowships contact consortiasales@bmjgroup.com

Visit casereports.bmj.com for more articles like this and to become a Fellow 